\title{
Analysis and Characterization of Bioethanol From Banana (Musa Acuminata Balbisiana) Peel Pulp By Yeast Enzymatic Production
}

\author{
Khusna Widhyahrini ${ }^{1, *}$, Endah Nur Hidayati ${ }^{2}$ \\ 1 Postgraduate Program, Pendidikan Guru Madrasah Ibtidaiyah (PGMI), IAIN Salatiga, Salatiga, Indonesia \\ 2 Tadris IPA Division, Fakultas Tarbiyah dan Ilmu Keguruan (FTIK), IAIN Salatiga, Salatiga, Indonesia \\ *E-mail: khusna@iainsalatiga.ac.id
}

DOI: https://doi.org/10.26874/jkk.v2i2.32

Received: 30 July 2019, Revised: 19 Aug 2019, Accepted: 20 Aug 2019, Online: 30 Nov 2019

\begin{abstract}
Banana (Musa acuminata balbisiana) peel had some potential using, especially in bioethanol. It was indicated that Banana peel (Musa acuminata balbisiana) had carbohydrates abundance. Banana (Musa acuminata balbisiana) peel can be cropped in some season, not only in a specific seasons. So that, Banana (Musa acuminata balbisiana) peel could be gotten easily. Banana (Musa acuminata balbisiana) peel as the trash is usually thrown away or animal feed needed. Banana (Musa acuminata balbisiana) peel had carbohydrate higher content, so it gave a lot of potential in bioethanol application. But, we needed to understand about the results of fermentation process. Characterization had been done to understand the fermentation of Banana peel product. The raw materials gotten from dried Banana peel with the amount of 50 gram in each of $100 \mathrm{ml}$ beaker glass. The yeast solution had been made in $15 \%$ $(\mathrm{w} / \mathrm{v}), 25 \%(\mathrm{w} / \mathrm{v})$, and $35 \%(\mathrm{w} / \mathrm{v})$ in water solvent. The fermentation process was carried out during 96 hours, then the clear liquid was separated by decantation process from the mixture. The distillation process was done to purify the product on $80{ }^{\circ} \mathrm{C}$. The distillate was measured by Fourier Transform Infrared (FTIR) spectroscopy to identify the specific peaks. The FTIR measurement was used Octagonal Cell Windows FTIR Prestige 21 Shimadzu. The FTIR spectrum showed characteristic peaks of bioethanol at $3404.01 \mathrm{~cm}^{-1}$ (-OH bonds); $2933.54 \mathrm{~cm}^{-1}$ (-C-H bonds); and $1011.06 \mathrm{~cm}^{-1}$ (-C-O bonds). From the FTIR analysis could be concluded that fermentation of Banana peel gave bioethanol
\end{abstract}

Keywords: Bioethanol, Banana peel, yeast, fermentation process, Biocatalyst

\section{Introduction}

Bioethanol had been known as alternative fuel beside of crude oil application [1,2]. Bioethanol gave more advantages in energy efficiency or its raw material. Bioethanol could be obtained from mono glucose or carbohydrates hydrolysis steps reaction [3-5]. Banana (Musa acuminata balbisiana) peel was thrown away or animal food using. High carbohydrate composition could had been any advantages as bioethanol resources [6,7].

Bioethanol synthesis process had be developed to give optimize product in quality and quantity by various methods. The optimizing of bioethanol synthesis process can be done by the raw material and hydrolysis mechanism reaction. Hydrolysis reaction of glucose was done by using kind of catalysis to improve its product. The acidbase catalyst such as $\mathrm{H}_{2} \mathrm{SO}_{4}, \mathrm{ClSO}_{3} \mathrm{H}, \mathrm{NaOH}$ could be used to hydrolyze carbohydrates, but it had any lack of in separation of its product [8-10].

Biocatalysts was familiar in some reaction. Enzyme was used as biocatalysis had regioselective in the reaction mechanism and did not need extreem condition ih high temperature and pressure, especially for glucose hydrolysis [11-14]. Biocatalysts effectivity was be solution to separate product from the reactant in reaction mixture, but it had any weakness in reusability, unstable in $\mathrm{pH}$ and temperature changing, also not economical [15]. The main problem to obtain bioethanol is purify it from its mixture from reactant, it can be solved by immobilization and impregnation $[16,17]$. There were some methods to increase reusability of enzyme, but there was not economically especially need chemical matrix or impregnation media. 
Yeast (Saccharomyces cerevisae) could be gotten easily, it obtained hydrolysis enzyme to convert carbohydrate to bioethanol in water solvent effectively [18, 19]. In this research, Banana peel pulp was fermented by yeast solution. The product was analyzed by using Octagonal Cell Windows FTIR Prestige 21 Shimadzu. Novelty of this research was about synthesis bioethanol in Banana (Musa acuminata balbisiana) peel pulp.

\section{Materials and Methods}

\subsection{Materials}

Banana peel (Musa acuminata balbisiana) was ggotten from Suruh village, Salatiga region. Comercial yeast (Saccharomyces cerevisae) and water. The apparatuses were used seems like 100 $\mathrm{ml}$ Erlenmeyer, magnetic stirrer, Erlenmeyer, distillation set, and Octagonal Cell Windows FTIR Prestige 21 Shimadzu.

\subsection{Methods \\ Banana pulp peel Preparation}

Banana (Musa acuminata balbisiana) pulp peel were made by grinding. The amount of 50 gram Banana peel pulp were put on each of three $250 \mathrm{~mL}$ beaker glass.

\section{Yeast Solution Preparation}

Yeast solution were done by various concentration of yeast are 15\% (w/v), 25\% (w/v), and $35 \%$ in water solvent.

\section{Fermentation Process}

Fermentation was done by blending $15 \%$ $(\mathrm{w} / \mathrm{v}), 25 \%(\mathrm{w} / \mathrm{v})$, and $35 \%(\mathrm{w} / \mathrm{v})$ banana pulp peel in water solvent. The mixture was homogenized by stirring then keep on room temperature for 96 hours.

\section{Purification}

After 96 hours, the clear liquid have been separated from the mixture of banana pulp peel and it solvent by using filtration process. The clear liquid filtrate obtained was separated by distillation process at $78^{\circ} \mathrm{C}$. The distillates were characterized by Fourier Transform Infrared (FTIR) spectroscopy.

\section{FTIR Characterization}

The distillates were characterized by Octagonal form Cell Windows FTIR Prestige 21
Shimadzu to understand some specific peaks for bioethanol structure.

\section{Result and Discussion}

The fermentation process was a monoglucose hydrolysis reaction to Ethanol $\left(\mathrm{C}_{2} \mathrm{H}_{5} \mathrm{OH}\right)$ synthesis [5], [18], [20]. Banana (Musa acuminata balbisiana) peel had a carbohydrates content of 1$20 \mathrm{~g} / 100 \mathrm{~g}$ as glucose resources, thus bioethanol producing [21,22].

Yeast (Saccharomyces cerevisiae) solution was made by dissolving yeast in various concentrations of $10 \%(\mathrm{w} / \mathrm{v}), 20 \%(\mathrm{w} / \mathrm{v})$, and $30 \%$ $(\mathrm{w} / \mathrm{v})$ in water solvent to understand physically that by various concentrations bioethanol could be made [23]. This study used Banana (Musa acuminata balbisiana) peel pulp porridge. the purpose of which is to do cellular destruction to obtain maximum carbohydrates [15].

- Banana (Musa acuminata balbisiana) peel pulp porridge was fermented for 96 hours at degree room temperature. Fermentation process was done in two steps, carbohydrates hydrolysis to glucose and glucose hydrolysis to ethanol was presented as shown below:

$$
\underset{\text { glukosa }}{\mathrm{C}_{6} \mathrm{H}_{2} \mathrm{O}_{6}} \stackrel{\text { ragi }}{\longrightarrow} \underset{\text { etanol }}{2 \mathrm{C}_{2} \mathrm{H}_{5} \mathrm{OH}}+2 \mathrm{CO}_{2}
$$

The clear liquid with ethanol aromatic specific was obtained from Banana (Musa acuminata balbisiana) peel pulp in yeast solution mixture fermentation process. The distillation process had been done to purify ethanol from water content at $80^{\circ} \mathrm{C}$. Distillat was characterized by using Octagonal form Cell Windows FTIR Prestige 21 Shimadzu. The FTIR spectrum of distillat was presentaed in Figure 1.

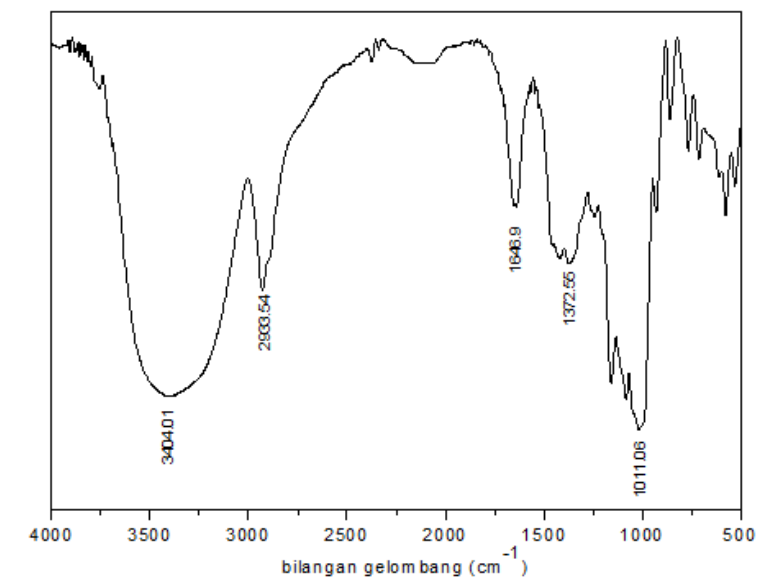

Figure 1. FTIR spectrum of Banana peel pulp fermentation distillat 
The sucsessfully of fermentation process of Banana (Musa acuminata balbisiana) peel pulp was indentified by FTIR spectrum. The FTIR spectra showed specific peaks of ethanol in range $500-4000 \mathrm{~cm}^{-1}$. The ethanol spectra were showed in waves number of $3404.01 \mathrm{~cm}^{-1}$ corresponded to streching vibration of hydroxyl bonds $(-\mathrm{OH})$, the peaks of wavenumbers of $2933.54 \mathrm{~cm}^{-1}$ towards to the streching vibration of $-\mathrm{CH}$ bonds for $\mathrm{CH}_{3}$ and $\mathrm{CH}_{2}$ region, and the peaks of wavemumbers of $1011.06 \mathrm{~cm}^{-1}$ toward to $-\mathrm{CO}$ bonds in alcohol structure $[24,25]$.

The FTIR spectra hepled to make sure about bioethanol liquid from Banana (Musa acuminata balbisiana) peel pulp. The structure of ethanol as for as bioethanol was very important to identify rather than scent test. By understanding about bioethanol potentially in Banana (Musa acuminata balbisiana) peel pulp, so it can be explored to use as alternative energy resources. Yeast was kind of enzyme sources for hydrolitic reaction and can be gotten economically. Yeast powder was solved in water to optimize the amount of enzyme-bond water [26]. Water solvent can help to open the lid of enzyme, so the active center could activate.

\section{Conclusion}

In this study, bioethanol could be obtained from the fermentation of Banana (Musa acuminata balbisiana) peel pulp in various concentration. The structure of bioethanol was confirmed by FTIR spectrophotometer measurements to identify some specific peaks of ethanol as a bioethanol.

\section{Acknowledgements}

Our gratitudes to Analytical Laboratory in Institut Teknologi Bandung (ITB) for the Octagonal form Cell Windows FTIR Prestige 21 Shimadzu measurements.

\section{References}

[1] K. Singh, S. D. Fernando, and R. Hernandez, "Base-catalyzed fast transesterification of soybean oil using ultrasonication," Energy and Fuels, vol. 21, no. 2, pp. 1161-1164, 2007.

[2] S. P. Singh and D. Singh, "Biodiesel production through the use of different sources and characterization of oils and their esters as the substitute of diesel: A review," Renew. Sustain. Energy Rev., vol. 14, no. 1, pp. 200-216, 2010.

[3] D. Park, S. Haam, K. Jang, I. S. Ahn, and W. S. Kim, "Immobilization of starchconverting enzymes on surface-modified carriers using single and co-immobilized systems: Properties and application to starch hydrolysis," Process Biochem., vol. 40, no. 1, pp. 53-61, 2005.

[4] G. A. Pereira, H. S. Arruda, G. Molina, and G. M. Pastore, "Extraction optimization and profile analysis of oligosaccharides in banana pulp and peel," J. Food Process. Preserv., vol. 42, no. 1, pp. 1-10, 2018.

[5] J. Wangpor, P. Prayoonyong, C. Sakdaronnarong, A. Sungpet, and W. Jonglertjunya, "Bioethanol production from cassava starch by enzymatic hydrolysis, fermentation and ex-situ nanofiltration.," Energy Procedia, vol. 138, pp. 883-888, 2017.

[6] D. Mohapatra, S. Mishra, and N. Sutar, "Banana and its by-product utilization: an overview," J. Sci. Ind. Reseach, vol. 69, no. May, pp. 323-329, 2010.

[7] E. . O. V.A Adisa, "Carbohydrate and Protein Composition of Banana Pulp and Peel as Influenced by Ripening and Mold Contamination," Food Chem., vol. 25, pp. 85-91, 1987.

[8] Eric Bosch, Introduction of Macromolecular Science/Polymeric Materials into the Foundational Course in Organic Chemistry, vol. 1151. Washington DC: American Chemical Society, 2013.

[9] D. E. López, J. G. Goodwin, D. A. Bruce, and E. Lotero, "Transesterification of triacetin with methanol on solid acid and base catalysts," Appl. Catal. A Gen., vol. 295, no. 2, pp. 97-105, 2005.

[10] and H. Y.-H. Priambodo Ricky, Chen TengChien, Lu Ming-Chun, Geranken Aharon, iao Jiunn-Der, "Novel Technology for Biodiesel Production from Cooking and Waste Cooking Oil by Microwave Irradiation," in Energy Procedia, 2015, vol. 75, pp. 84-91.

[11] Y. Fang, X. Huang, P. Chen, and Z. Xu, "Polymer materials for enzyme immobilization and their application in bioreactors," South Korea, 2011.

[12] and N. H. Fukuda Hideki, Kondo Akihiko, "Biodiesel fuel production by transesterification of oils," J. Biosci. Bioeng., vol. 92, no. 5, pp. 405-416, 2001.

[13] H. Hattori, "Solid Base Catalysts: 
Generation, characterization, and catalytic behavior of basic sites," J. Japan Pet. Inst., vol. 47, no. 2, pp. 67-81, 2004.

[14] M. Kapoor and M. N. Gupta, "Lipase promiscuity and its biochemical applications," Process Biochem., vol. 47, no. 4, pp. 555-569, 2012.

[15] C. Mateo, V. Grazu, J. M. Palomo, F. Lopez-Gallego, R. Fernandez-Lafuente, and J. M. Guisan, "Immobilization of enzymes on heterofunctional epoxy supports," Nat. Protoc., vol. 2, no. 5, pp. 1022-1033, 2007.

[16] D. S. Clark and J. E. Baileyt, "A Mathematical model for restricted diffusion effects on macromolecule impregnation in porous supports," Biotechnol. Bioeng., vol. 27, pp. 208-213, 1985.

[17] R. A. W. Nur Royhaila Mohamad, Nur Haziqah Che Marzuki, Nor Aziah buang, Fahrul Hutop, "An overview of technologies for immobilization of enzymes and surface analysis techniques for immobilized enzymes," Biotechnol. Biotechnol. Equip., vol. 29, no. 2, pp. 205220, 2015.

[18] M. Jayaprakashvel, S. Akila, M. Venkatramani, S. Vinothini, S. J. Bhagat, and A. J. Hussain, "Production of bioethanol from papaya and pineapple wastes using marine associated microorganisms," Biosci. Biotechnol. Res. Asia, vol. 11, no. SepcialEdition, pp. 193 199, 2014.

[19] M. Klähn, G. S. Lim, A. Seduraman, and P. $\mathrm{Wu}$, "On the different roles of anions and cations in the solvation of enzymes in ionic liquids.," Phys. Chem. Chem. Phys., vol. 13, no. 4, pp. 1649-1662, 2011.

[20] S. H. Mohd Azhar et al., "Yeasts in sustainable bioethanol production: A review," Biochem. Biophys. Reports, vol.
10, pp. 52-61, 2017.

[21] B. A. G. Regina C Adao, "Food Chemistry Bioactive amines and carbohydrate changes during ripening of ' Prata' banana ( Musa acuminata $\cdot$ M . balbisiana )," Food Chem., vol. 90, pp. 705-711, 2005.

[22] C. M. Davis-McGibony, R. R. Bennett, A. D. Bossart II, and S. T. Deal, "An Alternative Procedure for Carbohydrate Analysis of Bananas: Cheaper and Easier," J. Chem. Educ., vol. 83, no. 10, p. 1543, 2006.

[23] B. Xia, G. Cheng, X. Lin, and Q. Wu, "Dynamic double kinetic resolution of amines and alcohols under the cocatalysis of Raney nickel/Candida antarctica lipase B: from concept to application," European J. Org. Chem., vol. 2014, no. 14, pp. $2917-$ 2923, 2014.

[24] I. Doroshenko, V. Pogorelov, and V. Sablinskas, "Infrared Absorption Spectra of Monohydric Alcohols Dataset Paper Infrared Absorption Spectra of Monohydric Alcohols," Dataset Pap. Chem., no. November 2015, pp. 1-8, 2013.

[25] M. A. S. R Wugt Larsen, Philipp Zielke, "Hydrogen-bonded $\mathrm{OH}$ stretching modes of methanol clusters: A combined IR and Raman isotopomer study Hydrogen-bonded $\mathrm{OH}$ stretching modes of methanol clusters : A combined IR and Raman isotopomer study," J. Chem. Phys., vol. 194307, no. 126, pp. 126-144, 2007.

[26] J. B. J. Neena N Gandhi, Nitin S Ptil, Sudhirprakash B Sawant, "Lipase Catalyzed Esterification," 2000. 